\title{
$\mathbf{F} \cdot \mathbf{O} \cdot \mathbf{R} \cdot \mathbf{U} \cdot \mathbf{M}$ \\ Perspectives on Canadian Population
}

\section{Canada: The case for stable population with moderately low fertility and modest immigration}

\author{
Roderic Beaujot ${ }^{1}$
}

\section{Introduction}

It is a pleasure to be invited to comment on Anatole Romaniuk's thoughtful discussion of stationary population as a policy option for Canada. Romaniuk (2017; this vol.) makes the case for stationary population in terms of "ecologists" long- term concerns," "economists' short-term concerns," and from the "point of view of national identity and social cohesion." The paper concludes that "stationary population policies are optimal for maintaining national identity, social cohesion, and material well-being." The author is correct in saying that demographers are often reluctant to engage these broad macro issues. I commend Frank Trovato in promoting such a discussion in Canadian Studies in Population.

\section{Stationary population defined}

Romaniuk (2017) defines a stationary population as a "configuration of zero population growth, with a reproduction rate slightly in excess of two births per woman" or a "population that, in the long run, settles around a zero growth rate or a total fertility of two births per woman." I would argue that this is one among various definitions of a stationary population. For instance, a cohort fertility of about 1.7 and a net annual immigration of about 0.6 per cent of the receiving population would also produce about zero population growth in the long run (see Kerr and Beaujot 2016: 117[fig. 5.4], 179).

At the world level, there is substantial agreement that we would be better off if the human population reached a maximum sooner rather than later (UN 1994). I would also agree that Canada should play its part in reaching this kind of stability. Clearly, it is impossible to achieve stability for the whole human population if the sub-parts are growing. Romaniuk's argument is especially useful in questioning the "populationist agenda" that is often "driving population policy." I also agree that "a more equitable distribution of wealth worldwide," and especially the promotion of health, education, and gender equality, would be the most efficient mechanisms to reduce fertility in countries that have not completed their demographic transition, and it would reduce outmigration pressure (see Lutz et al. 2014).

\section{Ecological perspectives}

While it may be self-evident, I would have liked the author to make the case for stationary population in relation to long-term ecologic concerns. Contrary to Malthus, we have come to find that the problem of limits does not involve food or other production but rather the "sinks" of production in terms of ecological impacts, including carbon-dioxide concentration and planetary warming. Of course, we want to reduce the impact through environmentally friendly technology and more environmental responsibility on the part of individuals, corpora-

1. Department of Sociology, Western University, London, Ontario, Canada; email: rbeaujot@uwo.ca. 
tions and states, but the discussion of environmental impacts pays insufficient attention to the multiplier of population. While Canada accounts for only 1.7 percent of global $\mathrm{CO}_{2}$ emissions, climate and distances make us one of the highest per capita emitters, after Saudi Arabia, Australia, and the United States (Kerr and Beaujot 2016: 307). Among the countries of the world, Canada is 37th in population size but 10th largest in terms of total $\mathrm{CO}_{2}$ emissions. While there may be some efficiency gains to a larger population, it is hard to see how a larger population would reduce the environmental impact (see Kerr and Beaujot 2016: 299-330).

That is, as Romaniuk observes, Canada needs to play its part in managing the "ecological health of our planet." Water is of particular concern, since its very abundance blinds us as to its real limits and wasteful usage. In Water Policy and Governance in Canada, Renzetti and Dupont (2017: 3) observe: "Canada's water resources face a number of significant challenges arising from population growth, natural resource-based developments, the looming implications of climate change, a growing reliance on large-scale irrigation, and a legacy of past laws and regulations unable to address these challenges adequately."

\section{Economic perspectives}

It would also be useful if Romaniuk would spell out the case for stable population in relation to "the short-term concerns of economists." John Stewart Mill is quoted to the effect that "the increase of wealth is not boundless," and thus we reach a point where increased improvements in per capita quality of life can best be achieved through "a stationary condition of capital and population." As Romaniuk proposes, the case for population growth is much less obvious when considering per capita quality of life rather than overall economic growth.

In $A$ Concise History of World Population, Massimo Livi-Bacci observes that while economies of scale have found much empirical support in the past 150 years, "beyond certain limits, demographic growth creates diseconomies of scale, reversing a trend which seems to have dominated much of human history" (2012: 257). While I do not know this literature, the Australian agricultural economist Jane O'Sullivan (2012) makes the case that stable populations, rather than growing ones, have less need for investments in infrastructure. O'Sullivan proposes that population stabilization is a powerful lever that diminishes resource consumption and environmental impact, reverses income inequality, and increases per capita utility without expanding the economy. In contrast, population growth can have elements of a Ponzi scheme, which benefits the dominant class much as the "reserve army of labour" benefits capital.

My reading of the economic literature is that it is overwhelmingly pro-population growth and that John Stewart Mill is an outlier. For instance, a report from The Conference Board of Canada (2016) argues that higher levels of immigration have the potential to increase the growth of Canada's labour force and generate higher economic growth. In a fairly balanced summary of the economic argument on population growth, John Ibbitson (2017) proposes that population decline through low births would "ease strains on the environment." But Ibbitson goes on to observe that there would be "economic challenges, as increasing life expectancy and reduced fertility undermine health-care and pension systems. A shortage of young couples with children will reduce the market for housing, appliances and diapers. Labour shortages will increase, though productivity will improve to compensate." This summary does recognize that population decline would reduce the strains on the environment, and that reduced numbers entering the labour force would push in the direction of improved productivity. But the main thrust of Ibbitson's argument is promoting immigration to avoid population decline.

At the macro level, the real question, in my view, is whether to give priority to economic growth or ecological sustainability. Some time ago, Nathan Keyfitz (1989) observed that ecology and economics are rather different disciplines in terms of the time scale that they envision (eons of time vs. a short-term horizon) and what they optimize (sustainability vs. growth). I would side with Keyfitz, observing in particular that the economy bas to exist within the ecology. 


\section{Promoting childbearing}

Since he defines a stationary population as one with replacement fertility, Romaniuk discusses policy questions related to promoting childbearing. He makes the case that we need to rebalance the allocation of resources to production and reproduction by redefining "motherhood and childbearing from being a private good to being a public good" and making motherhood "much more fully rewarded...in the name of both distributive justice and demographic sustainability." He advocates "that all mothers should be paid the equivalent of their salary for a significant period of time, both to encourage them to become mothers and to ensure that they do not suffer discrimination and penalty for choosing motherhood."

While I agree that we should better support families with children, my own reading of the gender dynamics is that childbearing is best sustained in a country like Canada by pushing toward the completion of the second half of the gender revolution (see Goldscheider et al. 2015; Anderson and Kohler 2015). Peter McDonald (2000) had theorized that fertility is lowest when women have equal opportunities in the public domain (especially for education and jobs), but families allocate an excessive amount of the unpaid work to wives and mothers. Rather than encouraging some women to devote more time to childbearing, we need to complete the second half of the gender revolution (in the private domain), by ensuring that men, and the state, shoulder more of the burden. State support would best include a package of policies that supports families in terms of (1) parental leave (including dedicated paternal leave), (2) child care, (3) direct support for families through the tax system, housing or family allowance (Gauthier and Philipov 2008; Thévenon 2011; 2016; Brauner-Otto 2016). Rather than promoting men at work and women at home, fertility in post-modern countries is supported when institutional arrangements permit flexibility in terms of gender, work patterns and family forms (Héran 2013; Laplante 2013; Kravdal 2016).

Regardless of policy, it is unlikely that childbearing in a country like Canada would return to replacement levels. The literature has defined "lowest-low" fertility as a Total Fertility Rate (TFR) of 1.3 or lower (Kohler et al. 2002), and "very low fertility" in the range of 1.4 to 1.5 (Kohler and Anderson 2016). However, I would speak of a cohort fertility in the range of 1.6 to 1.8 as only "moderately low." I would propose that countries like Canada can avoid particularly low fertility through provisions that reduce the uncertainty as experienced by young adults, along with institutional arrangements that support families in various forms, and a package of policies that include parental leave, childcare, and direct benefits to parents (Beaujot and Wang 2010; Beaujot et al. 2013).

\section{A modest level of immigration}

I agree with Romaniuk that we are much too prone to think of immigration as the "solution to all problems" and the only area of deliberate demographic policy. Immigration does sustain the growth of the population, but it has rather modest impact on population aging, and it brings more unevenness in population distribution over space (Kerr and Beaujot 2016: 111-21). For instance, relative to the medium assumption on immigration levels, the high assumption produces an average age that is only one year younger in 2036 (Statcan 2010).

I also agree that immigration is a rather minor factor in per capita economic growth. For instance, Serge Nadeau (2011) finds that while immigration affects the overall size of the economy, it has a relatively modest effect on per capita measures. These conclusions are similar to those of a study by the Economic Council of Canada (1991) that found positive but very small effects of higher immigration on per capita income and on public sector costs (see Kerr and Beaujot 2016: 121-25).

Romaniuk's main concern with immigration is that it can undermine national identity and social cohesion. For instance, he observes that multicultural states or empires have often failed to achieve long-term social cohesion (e.g., Roman Empire, Austria, Soviet Union, Yugoslavia), while others are undergoing difficulties (Spain, Belgium, Canada, Great Britain). Switzerland and India are used as examples of successful multicultural adaptations. 
In paying particular attention to the demographics of subgroups in the Canadian case, Romaniuk cites the projections based on the 2006 Census to the effect that "one hundred years after the beginning of the projection, between 62 and 88 percent of the population would have either immigrated to Canada after 2006 or would be a descendant of someone who immigrated to Canada after 2006 (Dion et al. 2015: 118)." This counts "a descendant of [immigrants]" as any descendant of mixed unions between immigrants and those with an ancestor who was Canadian-born in 2006. This way of attributing identity is biased toward viewing the original population as being replaced by immigrants and their descendants. Knowing that immigrants and their descendants tend to integrate into the existing population, it would seem more appropriate to observe the percentage of the 2106 population that would have at least one Canadian-born ancestor in the 2006 population. At the very least, the expression "populations of foreign origin" should be replaced with "population with at least one foreign-born ancestor." The same difficulty applies to projections of the visible minority population, where all descendants of "mixed" unions are given the identity of visible minority status. As behavioural patterns and opportunities tend to converge over generations, these long-term projections are not particularly useful, except in showing the increased proportion of the population who have at least one ancestor with visible minority status.

We should be careful to avoid rigid definitions. It is interesting, for instance, that the Royal Commission on Bilingualism and Biculturalism evolved in the 1960s to adopt instead the concepts of "bilingualism" and "multiculturalism." As experienced in commemorating Canada's sesquicentennial, these concepts have proved insufficient for including the indigenous population, where we should speak of "time immemorial" as their presence in Canada rather than since Confederation in 1867.

Simply put, I find it difficult to make a case for stationary population based on questions of national identity and social cohesion. As Romaniuk observes: "not all is wrong with diversity as a social construct," and "a liberal society cannot be closed." I would argue that Canada has benefited from diversity in immigration, by place of origin, by socio-economic status, and by immigrant class (economic, family, refugee). Canadians have substantial interests in immigration, on personal grounds, for enhancing diversity and contacts in the globalizing world, and as humanitarian assistance to refugees (see Kerr and Beaujot 2016: 134-35).

\section{Conclusion}

I agree with Anatole Romaniuk's critique of a populationist agenda; this agenda is too fixated on growth at the macro level, too dependent on "trickle-down theory," and pays inadequate attention to per capita quality of life. As the planet is reaching the limits of the capacity to absorb the "sinks" of human production, Canada needs to play its part in reducing the impact, and population size is one of the factors. At the same time, I find that a stationary population based on replacement fertility is unnecessarily restrictive and it shuts us off to the benefits of immigration, especially in bringing Canada in contact with a globalizing world. Thus, I have argued for family policies that would enable us to maintain childbearing in the "moderately low" range, along with "modest" immigration levels. These objectives could be achieved with cohort fertility in the range of 1.6 to 1.8 births per woman, and immigration levels of 5.0 to 7.0 immigrants per 1,000 population.

\section{References}

Anderson, T., and H-P. Kohler. 2015. Low fertility, socioeconomic development, and gender equity. Population and Development Review 41(3):381-407.

Beaujot, R., and J. Wang. 2010. Low fertility in Canada: The Nordic model in Quebec and the U.S. Model in Alberta. Canadian Studies in Population 37(3-4):411-43.

Beaujot, R., C.J. Du, and Z. Ravanera. 2013. Family policies in Quebec and the rest of Canada. Canadian Public Policy 39(2):221-39. 
Brauner-Otto, S. 2016. Canadian fertility trends and policies: A story of regional variation, in Low Fertility, Institutions, and their Policies: Variations Across Industrialized Countries, edited by R.R. Rindfuss and M.K. Choe. Dordrecht: Springer, p. 99-130.

Conference Board of Canada. 2016. A Long-Term View of Canada's Changing Demographics: Are Higher Immigration Levels an Appropriate Response to Canada's Aging Population? Ottawa: Conference Board of Canada.

Dion, P., É. Caron-Malenfant, C. Grondin, and D. Grenier. 2015. Long-term contribution of immigration to population renewal in Canada: A simulation. Population and Development Review 41(1):109-26.

Economic Council of Canada. 1991. Economic and Social Impacts of Immigration. Ottawa: Economic Council of Canada.

Goldscheider, F., E. Bernhardt, and T. Lappegard. 2015. The gender revolution: Understanding changing family and demographic behavior. Population and Development Review 41(2):207-39.

Gauthier, A.H., and D. Philipov. 2008. Can policies enhance fertility in Europe? Vienna Yearbook of Population Research 6(2008):1-16, https://doi.org/10.1553/populationyearbook2008s1

Ibbitson, J. 2017. “Thank multiculturalism for our bright future.” The Globe and Mail, 4 May 2017, A4.

Héran, F. 2013. "Fertility and Family Support Policies: What Can We Learn From the European Experience." Keynote speech, Opening Ceremony, Conference of the International Union for the Scientific Study of Population, Busan, Republic of Korea, 26 August 2013.

Keyfitz, N. 1989. Reconciling Economic and Ecological Theory on Population. Working Paper 89-027. Vienna: International Institute for Applied Systems Analysis.

Kerr, D., and R. Beaujot. 2016. Population Change in Canada. 3rd edn. Don Mills, ON: Oxford.

Kohler, H-P., and T. Anderson. 2016. Divergent Demographic Destinies. Paper presented at session on Low Fertility, Population Association of America, Washington, DC, 4-6 April 2016.

Kohler, H-P., F.C. Billari, and J.A. Ortega. 2002. The emergence of lowest-low fertility in Europe during the 1990s. Population and Development Review 28(4):641-80.

Kravdal, O. 2016. Not so low fertility in Norway: A result of affluence, liberal values, gender-equity ideals, and the Welfare State, in Low Fertility, Institutions, and their Policies: Variations Across Industrialized Countries, edited by R.R. Rindfuss and M.K. Choe. Dordrecht: Springer, p. 13-47.

Laplante, B. 2013. Well-being of families, in Implications of Global Peak Population for Canada's Future, edited by A.P. Bélanger and B. Edmonston. Population Change and Lifecourse Strategic Knowledge Cluster Discussion Paper 2(1), p. 7-10. http://ir.lib.uwo.ca/pclc/vol2/iss1/

Livi-Bacci, M. 2012. A Concise History of World Population. 5th edn. Malden, MA: Wiley-Blackwell.

Lutz, W., W.P. Butz, and K.C. Samir (eds). 2014. World Population and Human Capital in the Twenty-First Century. Oxford: Oxford University Press.

McDonald, P. 2000. Gender equality in theories of fertility. Population and Development Review 26:427-39.

Nadeau, S. 2011. The economic contribution of immigration in Canada: Recent developments: What do we know? What does it mean for policy? Research Group on the Economics of Immigration. Ottawa: University of Ottawa.

O'Sullivan, J. 2012. The burden of durable asset acquisition in growing populations. Economic Affairs 32(1):31-7.

Renzetti, S., and D. Dupont (eds). 2017. Water Policy and Governance in Canada. New York: Springer.

Romaniuk, A. Stationary population, immigration, social cohesion, and national identity: What are the links and the policy implications? With special attention to Canada, a demographer's point of view. Forum: Opinion and Perspectives on Canadian Population Policy. Canadian Studies in Population 44(3-4):x-y. 
Statcan (Statistics Canada). 2010. Population Projections for Canada, Provinces and Territories, 2009 to 2036. Cat. No. 91 520-X. Ottawa: Statistics Canada.

Thévenon, O. 2011. Family policies in OECD countries: A comparative analysis. Population and Development Review 37(1):57-87.

2016. The influence of family policies on fertility in France: Lessons from the past and prospects for the future, in Low Fertility, Institutions, and their Policies: Variations Across Industrialized Countries, edited by R.R. Rindfuss and M.K. Choe. Dordrecht: Springer, p. 49-76.

UN (United Nations). 1994. Population and Development: Programme of Action Adopted at the International Conference on Population and Development, Cairo, 5-13 September 1994. New York: United Nations. 